\title{
EKSPLORASI POTENSI GULMA SIAM (CHROMOLAENA ODORATA) SEBAGAI BIOFUNGISIDA PENGENDALI PHYTOPHTHORA PALMIVORA YANG DIISOLASI DARI BUAH KAKAO
}

\author{
Radix Suharjo \& Titik Nur Aeny \\ Fakultas Pertanian Universitas Lampung, Jl. Sumantri Brojonegoro No. 1, Bandar Lampung 35145 \\ E-mail:radix_suharjo@yahoo.com
}

\begin{abstract}
Exploration on the potential of siam weed (Chromolaena odorata) as a biofungicide for controlling Phytophthora palmivora, the pathogen of cocoa pod rot. The research was aimed to investigate: (1) distribution and population of Chromolaena odorata (siam weed) in different land-uses (paddy field, untreated land, houseyard, roadside and river/irigation side) in Bandar Lampung, South Lampung, Tanggamus, and East Lampung; (2) effect of $C$. odorata extract on in-vitro growth of Phytophthora palmivora, (3) effect of $C$. odorata extract on development of fruit rot symptom caused by $P$. palmivora on cocoa pod in the laboratory and in the field. Collecting of $P$. palmivora isolates and recording distribution and population of $C$. odorata were conducted in several locations known as endemic areas of cocoa pod rot disease. The effect of $C$. odorata extract on the growth of P. palmivora on agar media and cocoa pods was determine in the Laboratory of Plant Disease, Plant Protection Department, Faculty of Agriculture, University of Lampung. Field experiment was performed in a cocoa plantation in Kemiling, Bandar Lampung. The results showed that $C$. odorata weed can be found in all of the land-uses surveyed, but the highest population was found in the untreated land-use. The tips (young leaves and stems) extract of $C$. odorata showed a greater inhibition effect on the growth of $P$. palmivora compared to the root extract. The tips extract showed the best inhibition in-vitro growth of $P$. palmivora at $40 \%$ concentration level, inhibited symptom development on cocoa pods in the laboratory at $50 \%$ concentration level, and on cocoa pods in the field at $60 \%$ concentration level.
\end{abstract}

Key words : cocoa pod rot, Phytophthora palmivora, Chromolaena odorata, tip extract, root extract

\begin{abstract}
ABSTRAK
Eksplorasi potensi gulma siam (Chromolaena odorata) sebagai biofungisida pengendali Phytophthora palmivora yang diisolasi dari buah kakao. Penelitian ini bertujuan untuk (1) mengetahui sebaran dan populasi Chromolaena odorata (gulma siam) pada berbagai strata penggunaan lahan (sawah, lahan kosong/terlantar, pekarangan, tepi jalan, bantaran/tepi sungai) di daerah Bandar Lampung, Lampung Selatan, Tanggamus dan Lampung Timur; (2) mengkaji pengaruh ekstrak $C$. Odorata terhadap pertumbuhan $P$. palmivora secara in vitro; (3) mengkaji pengaruh ekstrak $C$. odorata terhadap perkembangan $P$. palmivora pada buah kakao di laboratorium dan di lapangan. Penelitian dilaksanakan pada Maret-Oktober 2007. Koleksi isolat $P$. palmivora dan pencatatan sebaran populasi gulma siam dilakukan di daerah pertanaman kakao yang merupakan daerah endemik penyakit busuk buah. Pengujian pengaruh ekstrak gulma siam terhadap perkembangan P. palmivora secara in vitro dan pada buah kakao dilakukan di Laboratorium Penyakit Tumbuhan, Jurusan Proteksi Tanaman, Fakultas Pertanian Universitas Lampung. Pengujian lapangan dilakukan di kebun kakao milik penduduk di Kemiling, Bandar Lampung. Hasil pengamatan lapangan menunjukkan bahwa gulma siam dapat ditemukan di berbagai sistem penggunaan lahan, tetapi paling mudah dan banyak ditemukan tumbuh di lahan kosong yang tidak terawat. Hasil pengujian pengaruh ekstrak gulma siam secara in vitro menunjukkan bahwa ekstrak bagian pucuk (daun dan batang muda) lebih efektif dalam menghambat pertumbuhan P. palmivora daripada ekstrak bagian akar. Ekstrak pucuk tersebut memberikan kemampuan penghambatan terbaik terhadap pertumbuhan $P$. palmivora secara in vitro pada tingkat konsentrasi $40 \%$, menghambat gejala serangan $P$. palmivora pada buah kakao di laboratorium mulai pada tingkat konsentrasi 50\%, dan menghambat gejala busuk buah kakao di lapangan pada tingkat konsentrasi $60 \%$.
\end{abstract}

Kata kunci : buah kakao, Phytophthora palmivora, Chromolaena odorata, gulma siam, ekstrak pucuk, ekstrak akar

\section{PENDAHULUAN}

Penyakit busuk buah merupakan salah satu penyakit penting di pertanaman kakao. Di Indonesia, penyakit ini menyebabkan kerugian yang cukup besar karena intensitas serangan mencapai $15-20 \%$ (Drenth $\&$ Sendall, 2004) dan mengakibatkan penurunan produksi buah kakao hingga mencapai 20-50\% (Purwantara et 
al., 2004). Sampai saat ini, penyakit busuk buah kakao belum dapat dikendalikan dengan baik. Pengendalian secara kultur teknis, pembuangan buah yang terinfeksi, dan penggunaan varietas tahan, ternyata tidak efektif untuk menekan kerugian akibat penyakit ini (Purwantara et al., 2004), sedangkan penggunaan berbagai jenis fungisida tembaga, asam fosfat dan metalaksil yang dilaporkan efektif ternyata menimbulkan dampak negatif bagi pengguna, konsumen dan lingkungan. Selain itu, harga pestisida yang semakin mahal juga menjadi permasalahan bagi petani.

Saat ini, pencarian alternatif pengendalian yang lebih efektif, murah, aman, dan ramah lingkungan menjadi prioritas utama. Salah satu alternatif sedang banyak diteliti dan dikembangkan adalah penggunaan pestisida nabati. Pestisida nabati menjadi pilihan antara lain karena bahan-bahannya yang melimpah di alam sehingga mudah ditemukan, mudah dibuat, mudah diaplikasikan, dan tidak menimbulkan dampak negatif bagi pengguna, konsumen, maupun lingkungan.

Menurut Prijono \& Triwidodo (1994), bahan tanaman yang digunakan sebagai pestisida nabati hendaknya tidak memiliki nilai ekonomi yang lebih tinggi bila digunakan untuk keperluan lain. Oleh sebab itu, usaha pemanfaatan bahan-bahan tanaman yang tidak mempunyai nilai ekonomis tinggi tetapi mempunyai potensi sebagai biopestisida, gulma misalnya, saat ini perlu lebih banyak diteliti. Salah satu jenis gulma yang dilaporkan mempunyai potensi tersebut adalah gulma siam atau nama lainnya adalah rumput merdeka atau putihan (Chromolaena odorata).

C. odorata dilaporkan mengandung senyawa kimia yang bersifat antibakteri terhadap patogen tumbuhan Xanthomonas vesicatoria dan Ralstonia solanacearum (Sukanya et al., 2009). Ekstrak gulma ini juga dilaporkan bersifat anti jamur terhadap Apergillus niger (Owolabi et al., 2010), dan Drechslera heveae (Ogbebor \& Adekunle, 2008). Tidak tertutup kemungkinan bahwa ekstrak gulma siam juga mampu menghambat pertumbuhan $P$. palmivora, yaitu jamur penyebab penyakit busuk buah kakao. Oleh karena itu, perlu dilakukan penelitian tentang potensi ekstrak gulma siam untuk menekan $P$. palmivora, penyebab penyakit busuk buah kakao di Indonesia.

\section{METODE PENELITIAN}

Penelitian ini dilaksanakan dalam empat subpercobaan, yaitu (1) studi sebaran $C$. odorata (gulma siam) pada lahan sawah, lahan kosong, pekarangan rumah, tepi jalan, dan bantaran/tepian sungai, (2) pengujian kemampuan ekstrak $C$. odorata (gulma siam) untuk menghambat perkembangan Phytophthora palmivora secara in vitro, (3) pengujian kemampuan ekstrak $C$. odorata (gulma siam) untuk menghambat perkembangan $P$. palmivora pada buah kakao di laboratorium dan (4) pengujian kemampuan ekstrak $C$. odorata (gulma siam) untuk menghambat perkembangan $P$. palmivora pada buah kakao di lapang.

Berbagai sistem penggunaan lahan yang diamati adalah lahan sawah (daerah persawahan), lahan kosong yang tidak dirawat atau tidak dimanfaatkan, pekarangan rumah (lahan di sekitar rumah), tepi jalan dan bantaran/ tepian sungai (pinggiran saluran irigasi atau sungai).

Studi Sebaran Chromolaena odorata. Kajian ini dilakukan untuk memperoleh informasi tentang lokasi tempat gulma siam tumbuh dan mudah ditemukan. Informasi ini akan menunjukkan tingkat ketersediaan gulma siam sebagai bahan biopestisida yang ada di wilayah Lampung. Penelitian dilakukan dengan melakukan survei pada lahan sawah, lahan kosong, pekarangan rumah, tepi jalan, dan bantaran/tepi sungai. Penghitungan besarnya populasi gulma siam mengacu pada metode yang dilakukan oleh Haryati et al. (2004) dengan beberapa modifikasi.

Pengamatan dan penghitungan populasi gulma siam dilakukan dengan melakukan survei pada lahan sawah, lahan kosong, pekarangan rumah, tepi jalan dan bantaran sungai di wilayah Bandar Lampung, Lampung Selatan dan Tanggamus. Dari setiap kabupaten dipilih empat kecamatan yang dapat mewakili seluruh wilayah, dan dari setiap kecamatan dipilih tiga kelurahan. Survei dilakukan dengan cara menentukan titik start/awal, kemudian berjalan maju dan berhenti pada setiap $500 \mathrm{~m}$ untuk menentukan luasan 5 x 5 m pada tiap-tiap sistem penggunaan lahan sebagai luasan contoh. Populasi gulma siam diukur dengan ketentuan satu populasi gulma siam merupakan gulma siam yang tumbuh pada luasan $1 \mathrm{x} 1 \mathrm{~m}$.

Pengamatan dilakukan terhadap populasi gulma siam yang ada di setiap sistem penggunaan lahan di masing-masing daerah yang telah ditentukan. Data yang dikumpulkan berupa populasi gulma siam di setiap sistem penggunaan lahan, sehingga pada akhirnya akan didapatkan informasi tentang ketersediaan gulma ini di setiap lokasi.

Daya Fungisida Ekstrak $C$. odorata. Percobaan tahap kedua ini dilakukan untuk mempelajari kemampuan ekstrak gulma siam dalam menghambat pertumbuhan in vitro P. palmivora. Metode penelitian yang digunakan mengacu pada metode yang digunakan oleh Kardinan (2000), Prasetyo et al. (2003), dan Haryati et al. (2004) yang telah dimodifikasi. 
Jamur P. palmivora diisolasi dari buah kakao terinfeksi di lapangan, dengan cara lebih dahulu mendisinfeksi permukaan buah kakao tersebut dengan alkohol $70 \%$, lalu membuat potongan-potongan kecil jaringan kulit buah kakao pada perbatasan jaringan sakit dan sehat kemudian ditanam/diinokulasi pada permukaan cawan petri berisi media V-8. Pengamatan terhadap jamur yang tumbuh dilakukan empat hari setelah inokulasi. Identifikasi jamur dilakukan secara makroskopis dan mikroskopis (Barnett \& Hunter, 1987; Domsch et al., 1993). Selanjutnya, P. palmivora murni yang diperoleh disimpan dalam agar miring, ditutup dengan minyak parafin steril dan disimpan dalam almari pendingin untuk pengujian selanjutnya.

Ekstraksi dilakukan terhadap dua bagian gulma siam, yaitu akar dan pucuk (gabungan antara daun dan batang muda). Ekstraksi dilakukan dengan cara memblender secara terpisah masing-masing jaringan gulma tersebut sebanyak 1000 gram yang ditambah 1000 $\mathrm{ml}$ air. Setelah itu, suspensi kental masing-masing jaringan disaring mengunakan kain kassa. Hasil saringan tersebut selanjutnya disebut sebagai ekstrak kasar (crude extract; ekstrak dengan konsentrasi 100\%).

Penyiapan media berisi ekstrak gulma siam dilakukan untuk mendapatkan media cawan berisi ekstrak kasar gulma siam dengan tingkat konsentrasi 0 , 10, 20, 30, 40 dan 50\%. Konsentrasi 0\% merupakan media V8 tanpa penambahan ekstrak gulma siam. Konsentrasi 10, 20, 30, 40 dan 50\% dipersiapkan dengan cara mencampurkan masing-masing 10, 20, 30, 40 dan $50 \mathrm{ml}$ ekstrak kasar gulma siam dengan sejumlah media V-8 sehingga volume akhir menjadi $100 \mathrm{ml}$. Media dengan berbagai konsentrasi ekstrak gulma siam tersebut kemudian digunakan untuk pengujian penghambatan secara in vitro. Pengujian tersebut dilakukan dengan cara menumbuhkan biakan murni $P$. palmivora pada media cawan yang mengandung ekstrak sesuai dengan perlakuan. Biakan murni $P$. palmivora yang digunakan dalam pengujian ini diambil menggunakan bor gabus berdiameter $5 \mathrm{~mm}$ sehingga berbentuk cakram dan ditumbuhkan pada bagian tengah media cawan.

Perlakuan disusun dalam rancangan acak lengkap (RAL) dengan tiga ulangan. Pengamatan dilakukan setiap hari terhadap diameter koloni jamur yang tumbuh pada setiap perlakuan. Data diameter yang didapat merupakan rata-rata dari empat kali pengukuran. Data yang didapatkan kemudian dianalisis dengan sidik ragam dan dilanjutkan dengan uji beda nyata terkecil (BNT) pada taraf nyata $5 \%$.
Efikasi Ekstrak C. odorata di Laboratorium. Percobaan ini dilakukan untuk mengetahui kemampuan ekstrak gulma siam dalam menghambat perkembangan gejala serangan $P$. palmivora pada buah kakao. Metode penelitian yang digunakan mengacu pada metode yang pernah dilakukan oleh Sulaksono et al. (2002) yang telah dimodifikasi.

Tanaman uji yang digunakan adalah buah kakao muda sehat dengan ukuran diameter buah $\pm 10 \mathrm{~cm}$ yang diambil dari lapangan. Ekstrak gulma siam yang dipergunakan dalam pengujian ini adalah ekstrak dengan tingkat konsentrasi yang mampu menghambat pertumbuhan $P$. palmivora secara in vitro, pada percobaan sebelumnya. Langkah-langkah ekstraksi yang dilakukan sama dengan langkah ekstraksi pada percobaan sebelumnya. Buah kakao yang digunakan untuk pengujian didesinfeksi permukaannya dengan alkohol 70\%, kemudian direndam selama 60 detik dalam ekstrak gulma siam dengan konsentrasi sesuai perlakuan $(10,30,50,70$, dan 90\%), air steril sebagai kontrol (konsentrasi $0 \%$ ) dan fungisida mankozeb $2 \mathrm{~g} / \mathrm{L}$ digunakan sebagai pembanding). Setelah 60 detik, buah diangkat dan dikering-anginkan. Selanjutnya pada permukaan buah ditempelkan potongan cakram biakan murni $P$. palmivora berdiameter $\pm 5 \mathrm{~mm}$ lalu ditutup dengan selotip, dibungkus dalam kantong plastik transparan dan diinkubasi pada suhu kamar.

Perlakuan disusun dalam rancangan acak lengkap (RAL) dengan tiga ulangan. Satu unit percobaan terdiri atas tiga buah kakao. Pengamatan dilakukan setiap hari terhadap gejala busuk yang muncul pada buah. Data yang dicatat berupa rata-rata dari ukuran diameter terpanjang dan terpendek gejala busuk buah pada buah kakao. Data ukuran diameter gejala busuk buah dianalisis menggunakan sidik ragam dan dilanjutkan dengan uji beda nyata terkecil (BNT) dengan taraf nyata $5 \%$.

Efikasi Ekstrak $\boldsymbol{C}$. odorata di Lapangan. Percobaan ini dilakukan untuk mempelajari kemampuan ekstrak kasar gulma siam dalam menghambat perkembangan gejala serangan $P$. palmivora pada buah kakao di lapang. Informasi ini akan menunjukkan apakah ekstrak gulma siam cukup efektif sebagai biofungisida/fungisida nabati untuk mengendalikan jamur $P$. palmivora, penyebab penyakit busuk buah kakao.

Perlakuan terdiri atas empat tingkat konsentrasi ekstrak gulma siam, yaitu 20\%, 40\%, 60\%, dan $80 \%$; kontrol positif (tidak dilakukan penyemprotan) dan pembanding yaitu fungisida mankozeb dengan konsentrasi $2 \mathrm{~g} / \mathrm{L}$. Penentuan tingkat konsentrasi yang 
diaplikasikan didasarkan pada hasil percobaan tahap sebelumnya. Fungisida mankozeb digunakan sebagai pembanding karena banyak digunakan oleh petani kakao untuk mengendalikan penyakit busuk buah kakao. Satu unit percobaan terdiri atas lima buah kakao sehat yang terdapat pada satu pohon dan letaknya saling berdekatan.

Ekstrak gulma siam disiapkan dengan mengikuti prosedur seperti pada percobaan sebelumnya. Aplikasi ekstrak dilakukan dengan cara mengoleskannya secara merata pada permukaan buah kakao menggunakan kuas. Selanjutnya, potongan bentuk cakram biakan $P$. palmivora (diameter $5 \mathrm{~mm}$ ) diinokulasikan pada bagian tengah permukaan buah, lalu ditutup selotip dan dibungkus dengan plastik transparan.

Perlakuan pada percobaan ini disusun dalam Rancangan Acak Kelompok (RAK) dengan tiga ulangan. Pengamatan terhadap buah yang diberi perlakuan dilakukan setiap hari untuk mengetahui saat mulai munculnya gejala. Diameter gejala serangan yang tampak pada buah juga diukur setiap hari, dan dilakukan seperti pada percobaan di laboratorium yang telah dilakukan sebelumnya. Data serangan atau perkembangan gejala berupa diameter gejala busuk pada buah diolah menggunakan sidik ragam dan selanjutnya nilai tengah antar perlakuan diuji dengan uji beda nyata terkecil (BNT) dengan taraf 5\%.

\section{HASIL DAN PEMBAHASAN}

Daerah Sebaran Chromolaena odorata. Data hasil survei lapang terhadap sebaran gulma siam yang telah dilaksanakan di beberapa lokasi menunjukkan bahwa gulma ini dapat tumbuh di berbagai Sistem penggunaan lahan, yaitu sawah, bantaran sungai, lahan kosong, tepi jalan dan pekarangan. Pada semua daerah sampel yang diamati, lahan kosong yang tidak dirawat lebih banyak ditumbuhi oleh gulma siam dibandingkan dengan lahan lainnya (Tabel 1).

Rerata populasi gulma siam yang tertinggi terdapat pada lahan kosong, yaitu sebesar 13,70 atau 53\% dari keseluruhan populasi, sedangkan populasi terkecil terdapat pada pekarangan, yaitu sebesar 1,94 atau 8\% dari keseluruhan populasi (Gambar 1). Hasil uji statistik juga menunjukkan bahwa lahan kosong memiliki populasi yang secara nyata lebih tinggi dibandingkan populasi pada strata penggunaan lahan yang lainnya (Tabel 1).

Beberapa peneliti melaporkan bahwa gulma siam dapat ditemukan di beberapa daerah perkebunan, seperti perkebunan kelapa sawit, kelapa, jambu monyet, tebu, jeruk, jati, karet, kopi, teh, coklat, rambutan, kapas, tembakau dan lahan-lahan pertanian yang lain. Selain

Tabel 1. Sebaran populasi gulma siam di lima sistem pengunaan lahan (populasi/25 $\mathrm{m}^{2}$ )

\begin{tabular}{lccccc}
\hline \multirow{2}{*}{ Daerah sampel } & \multicolumn{5}{c}{ Sistem penggunaan lahan } \\
\cline { 2 - 6 } & Sawah & Lahan Kosong & Pekarangan & Tepi Jalan & Bantaran sungai \\
\hline Bandar Lampung & 1,08 & 12,31 & 2,40 & 7,02 & 0,92 \\
Lampung Selatan & 2,67 & 21,35 & 2,56 & 7,39 & 4,20 \\
Tanggamus & 3,05 & 7,43 & 0,85 & 2,38 & 1,24 \\
Rerata & $2,27 \mathrm{~b}$ & $13,70 \mathrm{a}$ & $1,94 \mathrm{~b}$ & $5,60 \mathrm{~b}$ & $2,12 \mathrm{~b}$ \\
\hline
\end{tabular}

Nilai rerata yang diikuti huruf yang sama menunjukkan tidak berbeda nyata pada uji BNT $(\mathrm{p}>0,05)$.

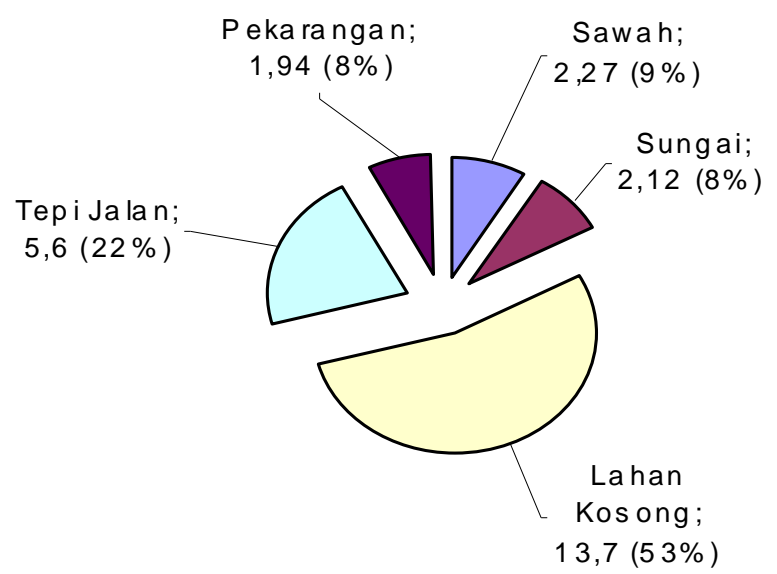

Gambar 1. Persentase sebaran gulma siam pada berbagai sistem penggunaan lahan 
itu, gulma ini juga dapat ditemukan di pinggir jalan, pinggir sungai, dan daerah hutan budidaya (Zachariades et al., 2009; Muniappan et al, 2005; Muniappan \& Bamba, 1999). Hasil survei yang telah dilakukan menunjukkan bahwa selain tempat-tempat yang disebutkan di atas, gulma ini ternyata juga dapat ditemukan di pekarangan rumah dan lahan kosong.

Habitat gulma siam yang cukup luas disebabkan karena gulma ini merupakan salah satu jenis gulma yang mudah tumbuh dan bersifat sangat invasive (Luwum, 2002; Zachariades et al., 2009). Ribuan bijinya yang terbentuk tersebar secara luas oleh angin dan berkecambah segera setelah lingkungan mendukung (Muniappan et al., 2005; Zachariades et al., 2009). Selain itu, gulma ini juga dikenal sebagai "tanaman marginal", yaitu jenis tanaman yang bisa tetap tumbuh baik di areal yang kurang subur atau areal yang tidak cocok bagi pertumbuhan tanaman lainnya (Handayani \& Prawito, 2006). Oleh karena itu, di daerah-daerah dengan tingkat kesuburan tanah yang rendah, angin yang cukup kuat berhembus, dan tidak ada campur tangan manusia (lahan kosong), akan didapatkan populasi gulma siam yang tinggi. Angin berperan dalam membantu penyebaran biji-biji gulma siam ke daerah-daerah di sekitarnya, dan tidak adanya usaha manusia untuk merawat dan mengolah lahan kosong, menyebabkan gulma siam dapat tumbuh tanpa ada gangguan. Sebaliknya, perawatan dan pengolahan lahan untuk budidaya tanaman akan membuat pertumbuhan gulma siam menjadi tertekan. Dengan demikian, daerah dengan kondisi angin yang cukup, dan sedikitnya campur tangan manusia seperti daerah pinggir jalan, bantaran sungai, sawah dan lahan kosong akan mempunyai populasi gulma siam lebih tinggi dari pekarangan.

Daya Fungisida Ekstrak $C$. odorata. Ekstrak dua bagian/jaringan tanaman gulma siam yaitu akar dan pucuk menunjukkan kemampuan yang berbeda dalam menghambat pertumbuhan P. palmivora (Gambar 2). Hasil uji statistik memperlihatkan bahwa ekstrak bagian pucuk tanaman mempunyai kemampuan penghambatan terhadap P. palmivora yang lebih baik daripada bagian akar (Tabel 2).

Diameter koloni jamur setelah perlakuan ekstrak pucuk lebih kecil dibandingkan dengan pada perlakuan ekstrak akar. Hal ini diduga karena senyawa-senyawa toksik, seperti alkohol, flavonones, khalkones, asam aromatik dan minyak essensial yang dikandung oleh gulma siam (Baruah \& Leclercq, 1993; Baruah \& Pathak, 1993; Collins \& Franzblau, 1997; Owolabi et al., 2010) lebih banyak terakumulasi pada bagian pucuk tanaman dari pada bagian akar. Untuk selanjutnya, investigasi akan difokuskan pada kemampuan ekstrak pucuk gulma siam (yang untuk selanjutnya akan ditulis sebagai ekstrak gulma siam) untuk mengendalikan $P$. palmivora.

Dari semua tingkat konsentrasi ekstrak gulma siam yang diuji, tingkat konsentrasi $40 \%$ menunjukkan penghambatan yang terbaik, meskipun tidak berbeda nyata dengan konsentrasi $30 \%$ (Tabel 3).
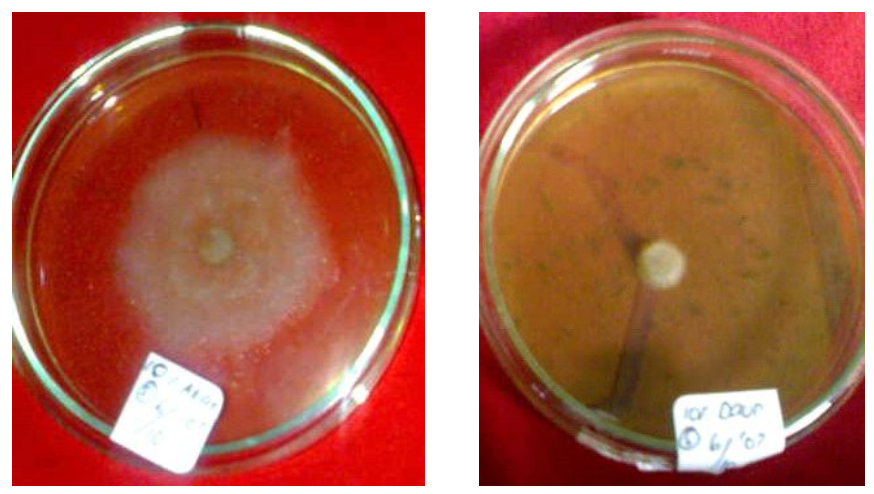

Gambar 2. Pertumbuhan koloni P. palmivora pada ekstrak akar (kiri) dan ekstrak pucuk (kanan) dengan konsentrasi $10 \%$ pada 2 hsi

Tabel 2. Pertumbuhan in vitro koloni $P$. palmivora pada perlakuan ekstrak akar dan pucuk gulma siam

\begin{tabular}{lc}
\hline \multicolumn{1}{c}{ Bagian gulma siam } & Diameter koloni $(\mathrm{mm})$ \\
\hline Akar & $69,9 \mathrm{a}$ \\
Pucuk (daun dan batang muda) & $25,7 \mathrm{~b}$ \\
\hline Angka yang
\end{tabular}

Angka yang diikuti huruf yang sama menunjukkan tidak berbeda nyata pada uji BNT 5\%. 
Efikasi Ekstrak $C$. odorata di Laboratorium. Ekstrak gulma siam menunjukkan efek penghambatan terhadap perkembangan gejala serangan $P$. palmivora pada buah kakao dengan tingkat penghambatan yang berbeda-beda pada setiap konsentrasi perlakuan. Pada sebelas hari setelah inokulasi, penghambatan secara signifikan mulai terlihat pada tingkat konsentrasi 50\% dan berlanjut sampai tingkat konsentrasi 90\% (Tabel 4).
Efek penghambatan oleh ekstrak gulma siam juga dapat dilihat dari grafik perkembangan diameter gejala pada tiap pengamatan yang tetap berada di bawah atau lebih rendah dari kontrol, dan bahkan juga lebih rendah dari fungisida pembanding (Gambar 3).

Gambar 3 menunjukkan bahwa pada setiap pengamatan, ekstrak gulma siam konsentrasi 50\% - 90\% dapat menekan perkembangan gejala tetap berada di

Tabel 3. Pertumbuhan in vitro koloni $P$. palmivora pada perlakuan ekstrak gulma siam dengan berbagai tingkat konsentrasi

\begin{tabular}{cc}
\hline Tingkat konsentrasi ekstrak gu lma siam $(\%)$ & Diameter koloni $(\mathrm{mm})$ \\
\hline 0 & $79,0 \mathrm{a}$ \\
10 & $53,0 \mathrm{~b}$ \\
20 & $41,8 \mathrm{c}$ \\
30 & $39,2 \mathrm{~cd}$ \\
40 & $34,0 \mathrm{~d}$ \\
50 & $39,9 \mathrm{c}$ \\
\hline
\end{tabular}

Angka yang diikuti huruf yang sama menunjukkan tidak berbeda nyata pada uji BNT $(\mathrm{p}>0,05)$.

Tabel 4. Diameter gejala serangan $P$. palmivora pada buah 11 hari setelah inokulasi

\begin{tabular}{cc}
\hline Tingkat konsentrasi ekstrak gulma siam $(\%)$ & Diameter gejala $(\mathrm{mm})$ \\
\hline 0 (kontrol) & $126,0 \mathrm{a}$ \\
10 & $121,3 \mathrm{ab}$ \\
30 & $123,3 \mathrm{ab}$ \\
50 & $109,5 \mathrm{bcde}$ \\
70 & $106,1 \mathrm{cde}$ \\
90 & $104,5 \mathrm{de}$ \\
Mankozeb & $118,8 \mathrm{abc}$ \\
\hline
\end{tabular}

Angka yang diikuti huruf yang sama menunjukkan tidak berbeda nyata pada uji BNT $(\mathrm{p}>0,05)$.

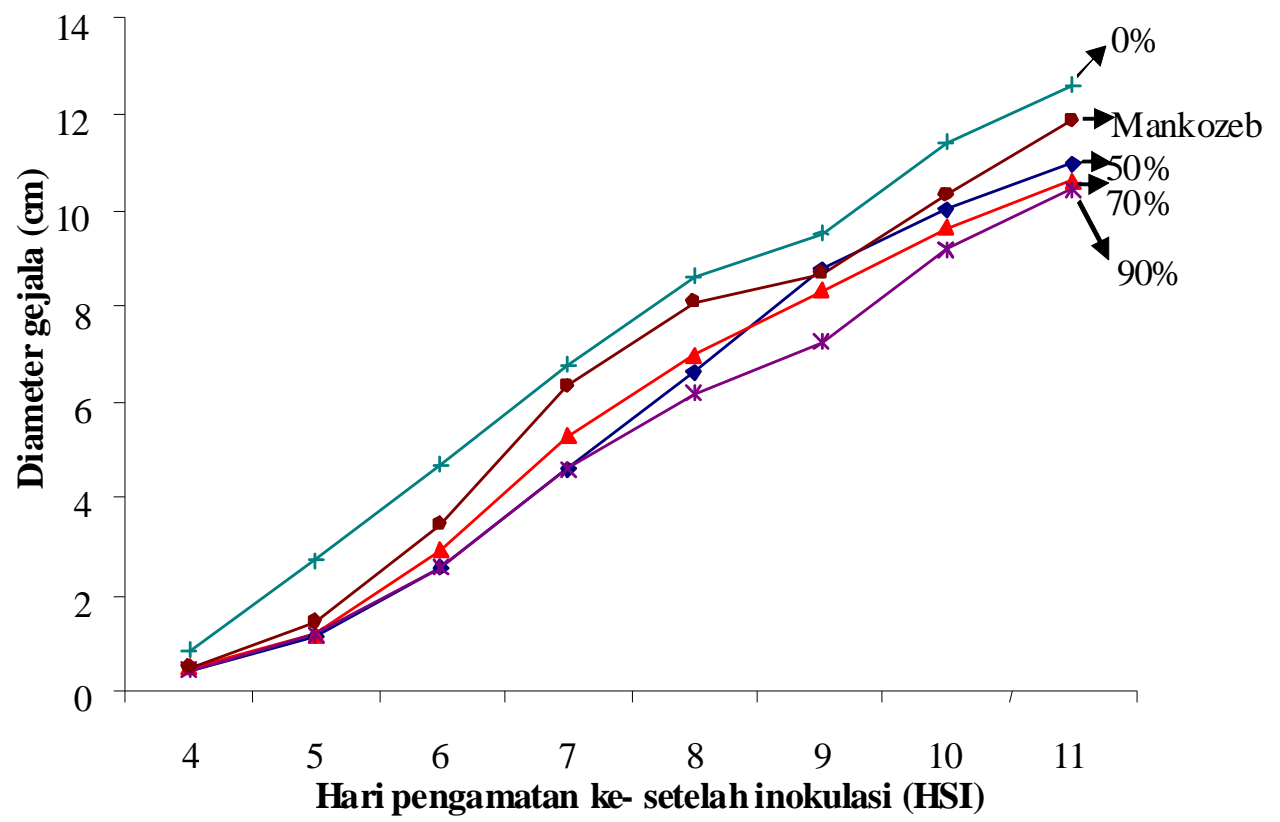

Gambar 3. Perkembangan gejala busuk buah kakao di laboratorium 
bawah kontrol, bahkan lebih rendah dari efek fungisida pembanding (mankozeb). Hal ini diduga karena ekstrak kasar gulma siam mempunyai batasan tingkat konsentrasi optimum untuk memberikan efek penekanan terhadap $P$. palmivora.

Efikasi Ekstrak $\boldsymbol{C}$. odorata di Lapang. Pengujian pengaruh ekstrak gulma siam terhadap perkembangan P. palmivora pada buah kakao yang dilakukan di lapang menunjukkan hasil yang mirip dengan pengujian di laboratorium (Tabel 5).

Apabila dilihat dari perkembangan diameter gejala serangan, terlihat bahwa konsentrasi $60 \%$, merupakan tingkat konsentrasi optimum bagi ekstrak gulma siam untuk menghambat serangan $P$. palmivora (Tabel 5 dan Gambar 4).

Hasil ini lebih menguatkan dugaan bahwa ekstrak gulma siam mempunyai batas tingkat konsentrasi optimum untuk menghambat serangan $P$. palmivora. Tingkat konsentrasi optimum ekstrak gulma siam terlihat berbeda untuk setiap tahap penelitian, dengan tingkat konsentrasi optimum tertinggi dicapai pada tahap penelitian lapang (60\%). Kondisi lapang yang tidak terkontrol diduga menjadi salah satu penyebabnya. Selain itu, ekstrak gulma siam yang digunakan dalam penelitian ini merupakan ekstrak kasar, sehingga kemampuannya masih jauh dibandingkan dengan ekstrak (senyawa) murni ataupun fungisida sintetik. Penelitian lebih lanjut untuk mendapatkan, mengidentifikasi dan mengaplikasikan senyawa murni dalam gulma siam yang mempunyai kemampuan untuk menekan pertumbuhan Phytophtora palmivora perlu dilakukan.

\section{SIMPULAN}

Gulma siam (C. odorata) terbukti dapat tumbuh di berbagai tempat, misalnya di sawah, bantaran sungai, tepi jalan dan lahan kosong, tetapi populasi terbanyak berada pada daerah lahan kosong. Ekstrak gulma siam bagian pucuk (daun dan batang muda) lebih efektif dalam menghambat pertumbuhan $P$. palmivora daripada bagian akar. Ekstrak gulma siam (bagian pucuk) memberikan kemampuan penghambatan terbaik terhadap pertumbuhan P. palmivora secara in vitro pada tingkat konsentrasi $40 \%$, menghambat gejala

Tabel 5. Diameter gejala serangan $P$. palmivora 5 hari setelah inokulasi

\begin{tabular}{cc}
\hline Tingkat konsentrasi ekstrak gulma siam $(\%)$ & Diameter gejala $(\mathrm{mm})$ \\
\hline 40 & $145,8 \mathrm{ab}$ \\
60 & $134,0 \mathrm{~b}$ \\
80 & $180,4 \mathrm{a}$ \\
90 & $188,3 \mathrm{a}$ \\
Kontrol & $148,4 \mathrm{ab}$ \\
\hline
\end{tabular}

Angka yang diikuti huruf yang sama menunjukkan tidak berbeda nyata pada uji BNT (p>0,05).

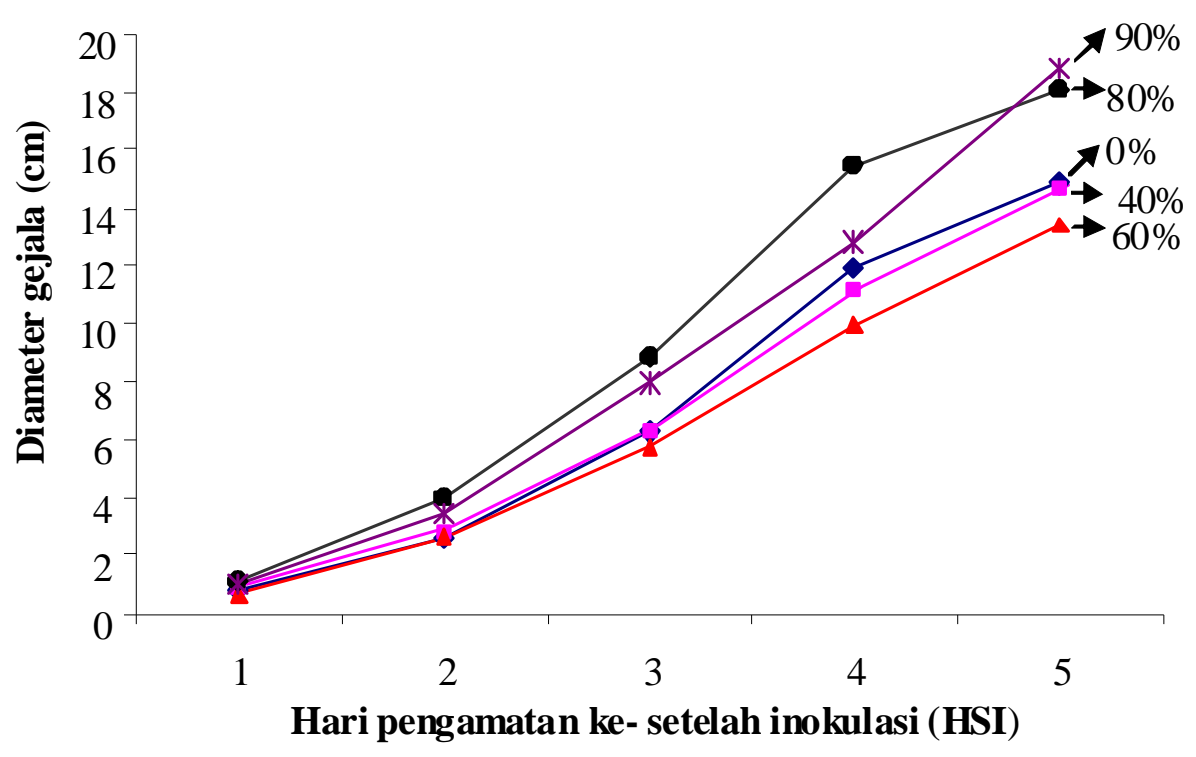

Gambar 4. Perkembangan diameter gejala busuk buah kakao di lapang 
serangan P. palmivora pada buah kakao di laboratorium mulai pada tingkat konsentrasi $50 \%$, dan menghambat gejala serangan $P$. palmivora pada buah kakao di lapangan pada tingkat konsentrasi $60 \%$.

\section{SANWACANA}

Penulis menyampaikan terima kasih kepada Dirjen Dikti melalui Program Hibah A2 Tahun 2007 Jurusan Proteksi Tanaman FP Unila yang telah mendanai penelitian ini, dan Ir. Joko Prasetyo, M.P. serta Dr. Suskandini Ratih atas diskusi dan masukan yang diberikan. Ucapan terima kasih juga penulis sampaikan kepada Otia Haryani Jasa S.P., M. Rozalo Velly S.P., dan I. Ricardo S.P. atas bantuannya dalam pelaksanaan penelitian ini.

\section{DAFTAR PUSTAKA}

Barnett HL \& Hunter BB. 1987. Illustrated genera of imperfect fungi. $4^{\text {th }}$ ed.New York. London. Macmillan. 218 pp.

Baruah RN \& Leclercq PA. 1993. Constituents of the essential oil from the flowers of Chromolaena odorata. Planta Med. (59): 283.

Baruah RN \& Pathak MG. 1993. Fatty acid compositions of Chromolaena odorata flower fat. Ind. J. Nat. Prod. (9): 17-18.

Collins LA \& Franzblau SG. 1997. Microplate Alamar BlueAssay versus BACTEC 460 system for highthroughputscreening of compounds against Mycobacterium tuberculosis and Mycobacterium avium. Antimicrob. Agents Chemother (41) : 1004-1009.

Domsch KH, Gams W \& Anderson T. 1993. Compendium of Soil Fungi. Vol 1. IHW-Verlag, Bert-Brech. 860 pp.

Drenth A \& Sendall B. 2004. Diversity and management of Phytophtora in Southeast Asia. Edited by A. Drenth \& D. I. Guest. Aciar Monograph 114.

Handayani IP \& Prawito P. 2006. Tumbuhan Perintis Pemulih Lahan Kritis : Kiat Petani Membangun Kesuburan Tanah. Yayasan Keanekaragaman Hayati Indonesia (KEHATI). Jakarta.
Haryati S, Hidayah N, Haryono K, Suharjo R, Soffan A $\&$ Swari FD. 2004. Pemanfaatan Ekstrak Gulma Siam (Chromolaena odorata) untuk mengendalikan Spodoptera exigua pada Pertanaman Bawang merah di Kretek, Bantul. Laporan Akhir Program Kreativitas Mahasiswa. Universitas Gadjah mada Yogyakarta (tidak dipublikasikan).

Kardinan A. 2000. Pestisida Nabati Ramuan dan Aplikasi. Penebar Swadaya, Bogor.

Luwum P. 2002. Control of Invasive Chromolaena odorata: An evaluation in some land use types in KwaZulu, South Africa. International Institute for Geo-Information Science and Earth Observation.

Muniappan R \& Bamba J. 1999. Biological Control of Chromolaena odorata: Successes and Failures. Proceedings of the X International Symposium on Biological Control of Weeds 4-14 July 1999, Montana State University, Bozeman, Montana, USA.

Muniappan R, Reddy GVP \& Lai PY. 2005. Distribution and biological control of Chromolaena odorata in Inderjit. Invasive Plants : Ecological and Agricultural Aspects. Birkhauser Verlag/ Switzerland $\mathrm{p}: 223-233$.

Ogbebor ON \& Adekunle AT. 2008. Inhibition of Drechslera heveae (Petch) M. B. Ellis, causal organism of Bird's eye spot disease of rubber (Hevea brasiliensis Muell Arg.) using plant extracts. Afr. J. Gen. Agric. 4 (1) : $19-26$.

Owolabi MS, Ogundajo A, Yusuf KO, Lajide L, Villanueva HE, Tuten JA \& Setzer WN. 2010. Chemical Composition and Bioactivity of the Essential Oil of Chromolaena odorata from Nigeria. Rec. Nat. Prod. 4 (1) : 72-78.

Prasetyo J, Mujim S \& Ginting C. 2003. Effects of Alpina galanga Powder on Phytophtora capsici Leionian In Vitro. Jurnal Hama dan Penyakit Tumbuhan Tropika 3 (2) : 36 - 39.

Prijono D \& Triwidodo H. 1994. Pemanfaatan Insektisida Nabati di Tingkat Petani. Prosiding Seminar Hasil Penelitian dalam Rangka Pemanfaatan Pestisida Nabati. Balai Penelitian tanaman Rempah dan Obat. Bogor, 1-2 Desember 1993. 
Purwantara A, Manohara D \& Warokka JS. 2004. Phytophtora Diseases in Indonesia. Principles of Phytophtora Disease Management. Edited by A. Drenth \& D. I. Guest. Aciar Monograph 114.

Sukanya SL, Sudisha J, Hariprasad P, Niranjana SR, Prakash HS \& Fathima SK. 2009. Antimicrobial activity of leaf extracts of Indian medicinal plants against clinical and phytopathogenic bacteria. African Journal of Biotechnology 8 (23): 66776682.
Sulaksono P, Umrah, Ramadhanil, Lamai PK \& Binangkari R. 2002. Efek Penghambatan ekstrak Daun Widuri (Calotropis sp.) terhadap Cendawan Busuk buah cabai (Collelotrichum capsici). Jurnal hama dan Penyakit Tumbuhan Tropika 2 (1) : $20-25$.

Zachariades, Day CM, Muniappan R \& Reddy GVP. 2009. Chromolaena odorata (L.) King and Robinson (Asteraceae) in Muniappan, R, G. V. P. Reddy \& A. Raman. Biological Control of Tropical Weeds using Arthropods. Cambridge University Press p:130 - 162. 